Paulina Pludra-Żuk

Warszawa

\title{
Aurora - wierszowana Biblia autorstwa Piotra Rigi (ok. 1145-1209): stan badań i perspektywy
}

Aurora, znana też jako Bibliotheca, od momentu powstania aż do końca średniowiecza cieszyła się szczególną popularnością. Ów tekst, spisany pod koniec XII w. przez Piotra Rigę (ok. 1145-1209), wykształconego w Paryżu kanonika katedry w Reims i kanonika mieszczącego się w tym mieście klasztoru augustianów, łączy w sobie kilka elementów kluczowych dla okresu, w którym powstał. Jest bowiem zarówno alegorycznym wykładem Biblii, obejmującym przede wszystkim księgi historyczne, spisanym w apogeum popularności tego rodzaju twórczości, jak i dziełem poetyckim, stanowiącym wzorzec stylu dla sobie współczesnych. Zasięg jego oddziaływania, wynikający między innymi z udanego połączenia tych dwóch aspektów, najprościej zobrazować, odwołując się do danych statystycznych dotyczących zachowanych po dziś dzień egzemplarzy Aurory, choć oczywiście na względzie mieć należy niedoskonałość tej przesłanki. Najbardzi ej szczegółowy spis dostępny w literaturze przedmiotu wylicza 250 istniejących kopii ${ }^{1}$. Obecnie jednak tę liczbę należy niemal podwoić - ostatnie publikacje wymieniają już 465 rękopisów $^{2}$, a wciąż liczyć można na nowe odkrycia. Obrazu dopełniają informacje odnoszące się do kopii już nieistniejących (w kweren-

\footnotetext{
2 Zob. G. Dinkova-Bruun, Corrector Ultimus: Aegidius of Paris and Peter Riga's 'Aurora', [w:] Modes of Authorship in the Middle Ages, ed. Slavica Ranković (Papers in Mediaeval Studies, 22), Toronto 2012, s. 172 (badaczka nie wymienia jednak poszczególnych rękopisów). Wcześniej listę zachowanych egzemplarzy uzupełnił o osiem pozycji P. E. Beichner, powołując się na Census of Medieval and Renaissance Manuscripts in the United States and Canada, ed. S. de Ricci, New York 1935-40 i jego kontynuację Supplement to the Census of Medieval and Renaissance Manuscripts in the United States and Canada, originated by C. U. Faye continued and ed. by W. H. Bond, New York 1962 - zob. Aurora: Petri Rigae Biblia versificata, ed. P. E. Beichner, Notre Dame 1965 (dalej cyt. Aurora...), t. 1, s. L, przyp. 80.
} 6825.

F. Stegmüller, Repertorium biblicum medii aevi, t. 4, Madrid 1954, nr 6823- 
dzie dotyczącej rękopisów związanych z terenami Polski do tej pory napotkałam wzmianki o siedmiu zaginionych bądź zniszczonych kopiach). Owe liczby stają się bardziej wymowne, gdy rozpowszechnienie Aurory porównamy chociażby z poematem Poetria nova Godfryda z Vinsauf tekstem, którego oddziaływanie było zbliżone pod względem chronologicznym (choć wykroczyło poza średniowiecze) i który podobnie cieszył się dużą popularnością jako utwór szkolny: zachował się on w liczbie mniejszej niż 200 egzemplarzy ${ }^{3}$.

Wraz z końcem XV wieku ten średniowieczny bestseller popadł w zapomnienie i - między innymi w związku z utrzymującym się przez wiele stuleci lekceważącym stosunkiem do średniowiecznej poezji pierwszego pełnego wydania drukiem doczekał dopiero w 1965 roku$^{4}$. Do tego czasu znany był jedynie z fragmentów zamieszczonych w serii Patrologia Latina 5 , w Spicilegium Solesmense ${ }^{6}$ i kilku siedemnasto- i osiemnastowiecznych wydaniach zbiorowych ${ }^{7}$. O planach edycji całości dzieła wspominał co prawda Casimir Oudin ${ }^{8}$, nie zdążył ich jednak zrealizować. Fragmentaryczna dostępność znacząco rzutowała na odbiór tekstu ${ }^{9}$, postrzeganego często jako średniowieczne kuriozum, zwłaszcza że drukiem ogłoszono w całości fragmenty mało reprezentatywne - najkrótsze księgi: Rut i Estery oraz specyficzne Recapitulationes, będące czymś w rodzaju ujętego w poetycką formę indeksu osobowego, cieszące się złą sławą u późniejszych krytyków ${ }^{10}$. Najnowszego wydania również nie można uznać za ostateczne. Jak bowiem podkreślił sam wydawca, jego założeniem było możliwie najszybsze udostępnienie badaczom jak najbardziej kompletnego tekstu, który

${ }^{3}$ M. C. Woods, A Medieval Rhetoric Goes to School - and to the University: The Commentaries on the Poetria nova, „Rhetorica: A Journal of the History of Rhetoric”, 9:1991, nr 1, s. 56.

${ }^{4}$ Por. wyżej, przyp. 2.

5 PL 212 (1855), kol. 9-46 (reprint z wyd. Polycarpa Leysera z dodatkami, por. niżej przyp. 7).

6 J.-B. Pitra, Spicilegium Solesmense, t. 2 i 3, Paris 1855, fragmenty rozproszone.

7 F. A. Zaccaria, Excursus litterarii per Italiam ab anno MDCCXLII ad annum MDCCLII, Venetiis 1754, s. 317-322; C. Oudin, Commentarius de scriptoribus ecclesiae antiquis, Leipzig 1722, t. 2, kol. 1551-1555; P. Leyser, Historia poetarum et poematum medii aevi, Halle 1721, s. 692-750, stanowiący podstawę dla PL; Caspar von Barth, Adversariorum Commentariorum Libri LX, Francofurti 1624, kol. 1456-1460.

${ }^{8}$ C. Oudin, Commentarius de scriptoribus ecclesiae antiquis, Leipzig 1722, t. 2 , s. 1551 .

9 Np. F. J. E. Raby w A History of Secular Latin Poetry in the Middle Ages, wyd. 2, Oxford 1957, t. 2, s. 35 błędnie przypisuje Ridze autorstwo wierszowanej parafrazy wyłącznie Starego Testamentu.

${ }_{10}$ Cf. np. F. J. E. Raby, A History of Christian-Latin Poetry from the Beginnings to the Close of the Middle Ages, wyd. 2, Oxford 1953, s. 303-304. 
z konieczności oparty został o ograniczoną liczbę dziewiętnastu egzemplarzy przechowywanych obecnie na terenie Stanów Zjednoczonych i Wielkiej Brytanii. Co za tym idzie, nie włączono do wydania choćby wielu mniej popularnych fragmentów o niewyjaśnionym autorstwie, niemożliwa stała się też dogłębna krytyka tekstu bardzo skomplikowanego pod względem tradycji. We wstępie do dzieła wydawca podał do dziś najpełniejsze, choć ze względu na charakter publikacji szkicowe, opracowanie tematu ${ }^{11}$. Wcześniejsze najbardziej wartościowe ogólne opracowania znaleźć można w Histoire littéraire de la Fran$c^{12}$ i w Geschichte der lateinischen Literatur des Mittelalters Maxa Manitiusa $^{13}$. W związku z tym, że Aurora nie doczekała się dotychczas większego zainteresowania w literaturze polskojęzycznej ${ }^{14}$, a ponadto brak uwspółcześnionego opracowania tego zagadnienia, opierając się poniżej przede wszystkim na stanie wiedzy, którą posiadał już P. E. Beichner ${ }^{15}$, uzupełniam stosowne miejsca o nowe ustalenia.

Otóż autorem tekstu był Piotr Riga, po francusku zwany Raie, Reige $^{16}$ lub Rigge ${ }^{17}$, a od późnego średniowiecza do XIX w. znany pod nieco zniekształconym imieniem Petrus de Riga. O jego życiu wiadomo niewiele. Urodził się w Reims ${ }^{18}$ (choć w starszych opracowaniach za miejsce jego urodzenia uważa się Vendôme ${ }^{19}$ lub nawet Anglię ${ }^{20}$ ) około roku $1145^{21}$, a kształcił w Paryżu. Następnie w rodzinnym mie-

11 Aurora..., t. 1, s. L-LIV.

${ }^{12}$ Histoire littéraire de la France, t. XVII, Paris 1832, s. 26-69 z uzup. t. XXX, Paris 1888, s. 608-615.

${ }_{13}$ M. Manitius, Geschichte der lateinischen Literatur des Mittelalters, t. 3, Münich 1931, s. 820-831; zob. też: E. Dümmler, Zu Petrus von Riga, „Neues Archiv der Gesellschaft für Ältere Deutsche Geschichtskunde”, 20:1895, s. 231-232. F. J. E. Raby, A History of Christian-Latin Poetry..., s. 303-304; tenże, A History of Secular Latin Poetry in the Middle Ages..., s. 35-38; C. Spicq, Esquisse d'une histoire de l'exégèse latine au moyen âge, Paris 1944, s. 72.

${ }_{14}$ Np. S. Wielgus, Badania nad Biblia w starożytności i w średniowieczu, Lublin 1990, s. 357, odwołuje się do Aurory wyłącznie jako do dzieła mnemotechnicznego. Zob. też S. Wielgus, Obca literatura biblijna w średniowiecznej Polsce, Lublin 1990, s. 113.

15 Aurora..., t. 1, s. VII-LV.

${ }_{16}$ Obie wersje podaje Histoire litteraire de la France, t. XXX, s. 608, bez odesłania do źródła.

17 Forma odnaleziona przez P. E. Beichnera w rękopisie British Library, Egerton 2951; zob. Aurora..., t. 1, s. XII.

${ }_{18}$ Aurora..., t. 1, s. XIII.

19 C. Oudin, dz. cyt., kol. 1551.

20 P. Leyser, dz. cyt., s. 692.

21 Data ustalona została na podstawie autobiograficznej wzmianki zamieszczonej w wierszu upamiętniającym narodziny Filipa Augusta. Riga wspomina w nim, że przebywał wówczas, czyli w roku 1165, w Paryżu („,Tunc mea Parisius studuit praesentia”), zob. Versus de gaudio filii regis quando fuit natus, wyd. F. Delaborde, Un poème inédit 
ście został kanonikiem katedry Notre-Dame, a później kanonikiem regularnym św. Augustyna w tamtejszym opactwie Saint Denis. Zmarł prawdopodobnie w 1209 r., pod tą bowiem datą jego śmierć odnotował piszący w 1241 r. Alberyk z Trois Fontaines: „W Reims zmarł pewien kanonik regularny św. Dionizego, magister Piotr zwany Riga, autor $\mathrm{Bi}$ blioteki, cieszący się wyjątkową sławą wśród scholarów i uczonych"22. Zarówno pierwotny tekst Aurory, jak i późniejsze wstępy dodają niewiele informacji biograficznych wykraczajacych poza konwencjonalne formuły ${ }^{23}$. Wartościowym pod tym względem okazało się natomiast krótkie encomium na cześć narodzin Filipa Augusta, które nie tylko pozwoliło na wyznaczenie przybliżonej daty urodzin Rigi, lecz także umieściło go w środowisku koterii tworzącej się wokół rodu Kapetyngów ${ }^{24}$. Skape informacje biograficzne starano się uzupełnić poprzez utożsamienie Rigi z bezimiennym kanonikiem z Szampanii, autorem bogatego w szczegóły autobiograficzne listu, wydanego przez Henri’ego Omonta w 1909 roku $^{25}$. Z takim postulatem wyszedł Paul Glorieux, opierając się na wyraźnym podobieństwie pomiędzy listą dzieł, które przypisywał sobie tenże kanonik, a zawartością Aurory. Na tej podstawie badacz wyraził przypuszczenie, że można Piotra Rigę powiązać z diecezją Châlons-sur-Marne, uznać za autora jedenastu wymienia-

de Pierre Riga sur la naissance de Philippe-Auguste, [w:] Notices et documents publiés pour la Société de l'Histoire de France à l'occasion du cinquantième anniversaire de sa fondation, Paris 1884, s. 121-127.

${ }^{22}$ „Remis moritur quidam Sancti Dyonisii canonicus regularis, magister Petrus, Riga cognominatus, Bibliothece versificator, apud scolares et studiosos opinione celeberrimus" - Chronica Albrici monachi Trium Fontium a monacho Novi Monasterii Hoiensis interpolata, ed. P. Scheffer-Boichorst, [w:] Monumenta Germaniae Historica, Scriptores (dalej cyt. MGH SS), t. XXIII, Hannoverae 1874, s. 889. Histoire Litteraire de la France, t. XVII, s. 26, podaje nieco odmienną wersję cytatu: „Remis moritur quidam sanctus canonicus regularis Sancti Dionisii, magister Petrus Riga, cognominatus Bibliotheca."

${ }^{23}$ Zob. także sporządzoną w 1492 r. charakterystykę pióra Johannesa Trithemiusa - Liber de ecclesiasticis scriptoribus, cap. 388, wyd. J. A. Fabricius, [w:] Bibliotheca ecclesiastica, Hamburgi 1718, pars 3, s. 98, gdzie Riga określony zostaje nie tylko jako „grammaticus” ale i ,philosophus, carmine excellens et prosa” oraz anonimową glosę cytowana w Histoire Litteraire de la France, t. XXX, s. 608-609, pochodzącą prawdopodobnie $\mathrm{z}$ XIII w.

${ }^{24}$ F. Delaborde, dz. cyt.; W. Ch. Jordan, Quando fuit natus: Interpreting the Birth of Philip Augustus, [w:] The Work of Jacques Le Goff and the Challenges of Medieval History, ed. M. Rubin, Woodbridge 1997, s. 171-88 (przedr.: W. Ch. Jordan, Ideology and Royal Power in Medieval France: Kingship, Crusades and the Jews, Aldershot 2001, s. 171-188, paginacja przejęta z I wydania).

$25 \mathrm{H}$. Omont, Lettre relative aux oeuvres d'un auteur champenois de la fin du XIIe siècle, „Notices et extraits des manuscrits de la Bibliothèque nationale”, t. XXXIX, I, Paris 1909, s. 24-27 (wyd. na podstawie rękopisu Paris, Bibl. nat. de France, Nouv. Acq. Lat. 886, f. 84-85). 
nych w liście dzieł i uzupełnić jego biografię o inne detale ${ }^{26}$. Szybko zauważono jednak, że niewielkich z pozoru różnic pomiędzy dziełami kanonika z Szampanii a Aurora nie da się łatwo wyjaśnić i że ich waga w praktyce uniemożliwia powiązanie tych dwóch postaci ${ }^{27}$. Ostatecznie najpewniejszą wydaje się argumentacja P. E. Beichnera, dowodzącego, że autor listu nie wylicza dzieł własnych, a jedynie - uciekając się do zabiegu retorycznego - przedstawia listę szkolnych lektur ${ }^{28}$. List kanonika z Szampanii prawdopodobnie nie przedstawia zatem żadnej wartości dla głębszego poznania biografii Piotra Rigi, stanowić może jednak najwcześniejszy dowód popularności jego dzieła.

Poza Aurora Riga jest też z pewnością autorem zbioru różnorodnych tekstów o charakterze zarówno religijnym, jak świeckim, znanego pod tytułem Floridus aspectus ${ }^{29}$, początkowo przypisywanego Hildebertowi

${ }^{26}$ P. Glorieux, Du nouveau sur Pierre Riga?, „Recherches de théologie ancienne et médiévale", 24:1957, s. 155-161.

27 J. R. Smeets, Du nouveau sur Pierre Riga?, „Recherches de théologie ancienne et médiévale", 28:1961, s. 334-337.

28 P. E. Beichner, The Champagne Letter Writer and Peter Riga, „Recherches de théologie ancienne et médiévale", 30:1963, s. 336-340.

${ }_{29}$ Zob. Venerabilis Hildeberti primo Cenomanensis episcopi, deinde Turonensis archiepiscopi, opera tam edita quam inedita. Acceserunt Marbodi Redonensis episcopi ipsius Hildebertisupparis opuscula, ed.A. Beaugendre, Paris 1708, kol. 1309-1370, przedr. [w:] PL 171, kol. 1381-1448. Skomplikowaną historię kolejnych wydań przedstawia C. Wollin, Der 'Floridus Aspectus'D des Petrus Riga: Erstausgabe nach der Handschrift Douai 825 (Teil I), „Mittellateinisches Jahrbuch”, 43:2008, nr 3, s. 355-360. Zob. też. B. Hauréau, Les Mélanges poétiques d'Hildebert de Lavardin, Paris 1882, s. 1-14 (przedr. $\mathrm{z}$,Notices et extraits des manuscrits de la Bibliothèque nationale”, 28:1878, nr 2, s. 289-448) - gdzie przedstawione zostają dowody przemawiające za uznaniem autorstwa Piotra Rigi, a za adresata zbioru zostaje uznany arcybiskup Samson; Ch. Fierville, Notice et extraits des manuscrits de la Bibliothèque de Saint-Omer nos. 115 et 710, „Notices et extraits des manuscrits de la Bibliothèque nationale”, 31:1884, nr 1, s. 49-156; British Museum, Catalogue of Additions to the Manuscripts (19161920), London 1933, s. 297-302 (opis najstarszego zachowanego rękopisu: MS. Egerton 2951); A. Boutemy, Thèses nouvelles et travaux en course, „Revue du moyen âge latin”, 1:1945, s. 340; tenże, Recherches sur le Floridus Aspectus de Pierre la Rigge I, „Le Moyen Age", 54:1948, s. 89-112; tenże, Recherches sur le Floridus Aspectus II oraz Recherches sur le Floridus Aspectus III, „Latomus”, 8:1949, s. 159-168 i 283-301; M. Manitius, Geschichte..., t. 3, s. 826-831; F. J. E. Raby, A History of Christian-Latin Poetry..., s. 303-304; tenże, A History of Secular Latin Poetry..., t. 2, s. 37-38. Lista poszczególnych utworów z odesłaniem do wydań: Histoire litteraire de la France, t. XXX, s. 611-614. Najnowsze publikacje dotyczące Floridus aspectus: C. Wollin, Das rhetorische Lehrgedicht 'Sensus et verba'des Petrus Riga, ,Revue Bénédictine”, 123:2013, nr 2, s. 319-369; C. Wollin, Der 'Floridus Aspectus' D des Petrus Riga: Erstausgabe nach der Handschrift Douai 825 (Teil II), „Mittellateinisches Jahrbuch”, 44:2009, nr 3, s. 407-447; C. Wollin, Der 'Floridus Aspectus'D des Petrus Riga: Erstausgabe nach der Handschrift Douai 825 (Teil I), „Mittellateinisches Jahrbuch”, 43:2008, nr 3, s. 355-391; C. Wollin, Die Troiagedichte des Petrus Riga in den Carmina Burana (CB 102 und CB 99a), ,Sacris Erudiri”, 43:2004, s. 393-425. 
$\mathrm{z}$ Lavardin ${ }^{30}$. Błąd ten, na podstawie analogii z pewnymi fragmentami $A u$ rory, sprostował Barthélemy Hauréau. Badacz zdecydował się jednocześnie na utożsamienie adresata zbioru z Samsonem, arcybiskupem Reims w latach 1240-1261. Zdawało się, że pozwala to wnieść nieco szczegółów do biografii samego Piotra i uznać go za protegowanego arcybiskupa, przy okazji rzucając światło na datację tekstu. Z pozoru umożliwiło też ustalenie chronologii dzieł Rigi, w której Floridus aspectus stanowi zbiór młodzieńczych utworów, będących pewnego rodzaju preludium do spisania prawdziwego opus magnum, jakim była sama Aurora. W późniejszej literaturze pojawiły się jednak zarzuty, że decyzję podjęto zbyt arbitral$n^{31}{ }^{31}$ i że ewentualna prawdziwość tezy nie może ostatecznie wpływać na ustalenie chronologii powstawania obu tekstów ${ }^{32}$.

Zarówno w średniowieczu, jak i bardziej współcześnie przypisywano Ridze też inne utwory. Części z tych atrybucji nie można wykluczyć być może Riga był np. autorem przywoływanego przez Alexanda de Villa Dei w Doctrinale traktatu De praeteritis et supinis ${ }^{33}$. Poza tym jednym przypadkiem wśród wymienianych tytułów pojawiają się jednak wyłącznie błędnie łączone $\mathrm{z}$ nim utwory cudze lub teksty skądinąd nieznane ${ }^{34}$. Wciąż jednak istnieje duże prawdopodobieństwo wzbogacenia listy jego dzieł o nierozpoznane dotąd pozycje, szczególnie, gdy analizie zostaną poddane kodeksy o charakterze miscellaneów, zawierające już wcześniej zidentyfikowane utwory Rigi. Takie nadzieje budzi między innymi kodeks znajdujący się obecnie w Bibliotece Jagiellońskiej ${ }^{35}$. Niedawno udało się powiązać Rigę z częścią utworów wchodzących w skład znanego $\mathrm{w}$ literaturze, choć nieudostępnionego w całości drukiem, miscellaneum

30 Tekst bywał również przypisywany Alanowi z Lille (zob. Hugon z Trymbergu, Registrum multorum auctorum, w. 293-96, Das Registrum multorum auctorum des Hugo von Trimberg: Ein Quellenbuch zur lateinischen Literaturgeschichte des Mittelalters I von J. Huemer, Wien 1888 (Sitzungsberichte der Akademie der Wissenschaften in Wien. Philosophisch-historische Klasse, 116/1), s. 145-190.

31 C. Wollin, Der 'Floridus Aspectus'... (I), s. 356.

${ }^{32}$ G. Antonelli, Per il testo dell' "Aurora» di Pietro Riga, „Studi medievali”, ser. 3, 32:1991, nr 2, s. 779 (,,pur ammettendo per esatta l'identificazione proposta dall'Hauréau, nulla vieta di credere che Pietro lo [sc. Sansone] celebrasse, come vivo, dopo la sua morte").

${ }^{33}$ Aurora..., s. XLII; Ch. Thurot, Notices et extraits de divers manuscrits latins pour sevir à l'histoire des doctrines grammaticales au moyen âge, „Notices et extraits des manuscrits de la bibliothèque impériale et autres bibliothèques, publiées par l'institut impérial de France", 22:1868, nr 2, s. 26-27; Histoire litteraire de la France, t. XXX, s. 614-615; D. Reichling, Das Doctrinale des Alexander de Villa-Dei: Kritisch-exegetische Ausgabe mit Einleitung, Verzeichniss der Handschriften und Drucke nebst Registern, Berlin 1893, s. LXXVI-LXXVII; M. Manitius, Geschichte..., t. 3, s. 829-830.

${ }^{34}$ Histoire litteraire de la France, t. XVII, s. 30.

35 C. Wollin, Der 'Floridus Aspectus'... (I), s. 358. 
dotychczas błędnie przypisywanego Hugo Metelowi, kanonikowi reguły św. Augustyna w Toul (Lotaryngia), żyjącemu w latach ok. 1080-ok $1150^{36}$.

Z pewnością największy rozgłos Piotrowi Ridze przyniosła Aurora. Wyjaśniając motywy, którymi się kierował, autor zgodnie z konwencją powołuje się na prośby szkolnych przyjaciół, nalegających, by oddał w metrum Pięcioksiag Mojżeszowy i wydobył jego alegoryczne znaczenie $^{37}$. Przypuszcza się zreszta, że Piotr rzeczywiście mógł się spotkać z takimi naleganiami i że spowodowane one były sławą, którą już wcześniej przyniosło mu autorstwo Floridi aspectus. Przez wzgląd na wspólną przeszłość - jak bowiem tłumaczy Riga, razem przecież uczyli się gramatyki, studiowali pisma Cycerona i wchodzili w labirynt pism Arystotelesa - podjął się spisania dzieła, które wywodząc alegoryczne znaczenia, rozjaśnić miało to, co skrywał Stary Testament ${ }^{38}$, jak jutrzenka (aurora) rozprasza ciemności nocy. A doprowadziwszy to męczące dzieło do końca, zwrócił się doń tymi samymi słowami, które anioł wypowiedział do Jakuba po nocnej walce: „dimitte me, aurora est" ${ }^{\prime 39}$.

Trzeba jednak powiedzieć po pierwsze, że - niezbyt adekwatnie do tytułu - Aurora do dziś skrywa w sobie wiele tajemnic, po drugie zaś, że autor walczył ze swym materiałem jeszcze długo po opublikowaniu pierwszej wersji dzieła, do której należy zacytowany powyżej wstęp. Uzupełnianie i poprawianie utworu trwać mogło nawet trzydzieści lat, do ok. 1200 r., a tymczasem szerszej publiczności udostępniane były kolejne wersje.

Jako pierwszy tę skomplikowaną tradycję rozpoznał P. E. Beichner ${ }^{40}$, któremu na podstawie przebadanych kodeksów udało się wyodrębnić trzy kolejne odautorskie wersje tekstu, spisane w latach ok. 1170-1200, oraz dwie nieco późniejsze redakcje, które prawdopodobnie jeszcze za życia autora, gdzieś pomiędzy rokiem 1200 (lub nieco wcześniejszą data) a 1208, sporządził Idzi z Paryża (o czym poniżej). Podstawową cechą wyróżniającą kolejne „edycje” jest ich stopniowo przyrastająca treść. I tak „edycja” pierwsza zawiera księgi: Rodzaju, Wyjścia, Kapłańska, Liczb, Powtórzonego Prawa, Jozuego, Sędziów, Rut, cztery Księgi Królew-

${ }^{36}$ C. J. McDonough, Hugh Metel and the Floridus Aspectus of Peter Riga (Staatsbibliothek zu Berlin Preussischer Kulturbesitz Phillipps 1694), „Mediaeval Studies”, 67:2005, s. 27-74; zob. też C. Wollin, Der 'Floridus Aspectus'... (I), s. 359-360.

37, ,...] ut librum Pentateucum Moysi stilo metrico depingerem et inde aliquas allegorias elicerem", Aurora..., t. 1, s. 7.

${ }^{38}$, ,...] tenebras umbrarum et veteris legis obscuritates discutiens, veritatis fulgore et allegoriarum scintillis micantibus totus refulgeat [...]", tamże, s. 8.

39 Tamże.

40 Tamże, s. XVII-XX. 
skie, dwie Księgi Machabejskie oraz niepełną treść Ewangelii. W drugiej „edycji”, po czwartej Księdze Królewskiej, pojawiają się ponadto księgi: Tobiasza, Daniela, Judyty i Estery, Ewangelia zostaje doprowadzona do końca i wzbogacona o prolog, pojawia się też księga Recapitulationes utwór lipogramatyczny podsumowujący treść wszystkich ksiag, a szczególnie przypominający imiona biblijnych postaci. W trzeciej „edycji” tekst uzupełniony został jeszcze o Dzieje Apostolskie, Księgę Hioba i Pieśń nad Pieśniami. Ostatnie trzy księgi spisano heksametrem, w przeciwieństwie do reszty utworu, w którym (poza prozaicznymi prologami) konsekwentnie zastosowano dystych elegijny. Poza samą zawartościa poszczególne wersje różnią się nieznacznie organizacją tekstu. W pierwszej „edycji” dłuższe księgi dzielone są na mniejsze partie; w kolejnych podział ten zanika, a nagłówki stają się bardziej precyzyjne. W wydaniu brak informacji na temat subtelniejszych różnic pomiędzy poszczególnymi wersjami, zauważona została jedynie tendencja do stopniowego, następującego wraz z kolejnymi ingerencjami w tekst, uwalniania się autora od wpływu języka wykorzystywanych źródeł. Gianfranco Antonelli, niestety bez oparcia w dogłębnej krytyce źródłowej, wyraża opinię, że Riga $\mathrm{w}$ kolejnych etapach pracy nad tekstem raczej go nie skraca, lecz uzupełnia o nowe elementy ${ }^{41}$. Gdyby tę tezę uznać za słuszna, można by na podstawie rozbudowania tekstu wnioskować o chronologii jego powstania. C. Wollin odrzuca jednak to kryterium jako nieuzasadnione ${ }^{42}$.

W tym miejscu - czyli po trzeciej ,edycji” odautorskiej - pojawia się postać Idziego z Paryża (łac. Aegidius, fr. Giles), którego tożsamość w dawniejszej literaturze nastręczała wiele trudności ${ }^{43}$. Ostatecznie wiadomo jednak, że nie chodzi tu ani o Idziego z Corbeil, medyka i autora poematów De pulsibus, De urinis i De antidotis, ani też o fikcyjnego Idziego Delphensis, lecz o Idziego urodzonego w 1162 r. w Paryżu, często podkreślającego swe paryskie pochodzenie i związanego z kościołem św. Marcela. Ów Idzi poza redakcjami Aurory znany jest z ukończonego ok. 1200 r. poematu Carolinus, w zamierzeniu mającego pełnić rolę podręcznika dla księcia Ludwika - późniejszego króla Ludwika VIII. W Aurorze Idzi przedstawia się jako corrector ultimus i wbrew wyrażeniom sugerującym skromność (mówi bowiem o sobie cliens, a o swoich dodatkach do tekstu, stanowiących blisko 6 tys. wersów ${ }^{44}$, portio quantu-

\footnotetext{
${ }^{41}$ G. Antonelli, dz. cyt., s. 784.

42 C. Wollin, Der 'Floridus Aspectus' D... (I), s. 376.

43 Histoire litteraire de la France, t. XVII, s. 36-38.

${ }^{44}$ G. Dinkova-Bruun, Aegidius of Paris and the Seven Seals: a Prose Prologue to the Gospels in Peter Riga's Aurora, „Mediaeval Studies”, 73:2012, s. 119.
} 
lacumque) i pomimo celowego przemilczenia swego imienia we wstępie do pierwszej redakcji, w rzeczywistości przywiązuje do swej pracy zaskakująco dużą wagę. Podkreśla rolę własnych zdolności (jest acutior ${ }^{45}$ ), które pozwoliły mu na przebudowanie dzieła stosownie do właściwego porządku, dwukrotnie liczy wprowadzone przez siebie wersy i oznacza je na marginesach za pomocą obelisków ${ }^{46}$. A choć praktyka znakowania wersów nie była w późniejszych kopiach zachowywana konsekwentnie, spotkać się z nią można jeszcze w egzemplarzach pochodzących z drugiej połowy $\mathrm{XV}$ wieku ${ }^{47}$. Jego precyzyjne obliczenia mogą dziś zresztą stanowić cenną wskazówkę dla krytycznego opracowania tekstu Aurory, pozwalają bowiem przypuszczać, że część przypisywanych Idziemu wersów wchodzących w skład Nowego Testamentu pochodzi w istocie od innego, anonimowego autora. W przeciwnym razie Idzi musiałby pominać 888 własnych wersów, a to - jak zauważa Greti Dinkova-Bruun - trudno sobie w tym przypadku wyobrazić. Badaczka, analizując charakter wprowadzanych przez correctora poprawek, odwołuje się do nieznanego dotychczas, a zachowanego tylko w trzech rękopisach, listu, który ów skierował do swego patrona - Odona. Jest to tekst tym cenniejszy, że pozwala na szersze spojrzenie na kwestię autorstwa w owym czasie. Idzi bowiem, przedstawiając motywy, którymi się kierował - dążył mianowicie do melioratio i dilucidatio - podkreśla wartość współczesnego autora (modernus) w konfrontacji z autorytetem. Można wobec tego uznać, że ta postawa sygnalizuje istotną zmianę w rozumieniu terminu author, który w XIII w. zaczyna zamiast „autorytetu” oznaczać „pisarza”48.

Idzi z Paryża ,chcąc zatem, zgodnie ze swym odczuciem, tekst uzupełnić i poprawić, opierając się na najpełniejszej wersji odautorskiej, sporządził kolejne dwa wydania. Oba ingerują przede wszystkim w układ dzieła, dostosowując go do kolejności ksiag biblijnych i przestawiając mniejsze partie tekstu. Wprowadzają ponadto uzupełnienia w miejscach pierwotnie pominiętych. Niekiedy tego rodzaju ingerencje znacząco wpływają na kształt poematu. Najwyraźniej widać to w dwóch przypadkach, mianowicie we fragmencie o Zuzannie (Księga Daniela), gdzie występujący w pierwotnej wersji dialog przeredagowany został na trzecioosobową relację, i w Ewangelii, w której wersy przestawiono tak gruntownie,

\footnotetext{
${ }^{45}$ Aurora..., t. 1, s. 11.

${ }^{46}$ „Nam quia sum libri consutor factus, ubique / Versiculis nostris pretytulatur acus”, Aurora..., t. 1, s. 16.

47 Takie oznaczenia, w przeważającej mierze odpowiadające ustaleniom P. E. Beichnera, napotkać można np. w rękopisie BJ 320, zawierającym tekst Aurory w pierwszej redakcji Idziego.

48 G. Dinkova-Bruun, Corrector Ultimus..., s. 172-189.
} 
że stworzyły właściwie nową całość. Idzi zaopatrzył ponadto Aurorę we własne wstępy.

Przedstawiony tu podział na kolejne wersje zapewne nie jest ostateczny. Istnieja przesłanki, by podejrzewać, że praca Rigi przebiegała bardziej stopniowo, część z przebadanych rękopisów zawiera bowiem tylko jedna $\mathrm{z}$ trzech ksiag dodanych $\mathrm{w}$ ostatniej redakcji, a zatem sugeruje istnienie stadium pośredniego, mieszącego się pomiędzy „edycją" drugą a trzecią ${ }^{49}$. Prawdopodobnie także Idzi wraz z drugą redakcją nie uznał swej pracy za skończona. Sugeruje to znany tylko z 13 rękopisów wstęp do Ewangelii ${ }^{50}$. G. Dinkova-Bruun zaznacza, że konieczne będzie ponadto zrewidowanie drugiej redakcji Idziego, której fragmenty wydane zostały przez P. E. Beichnera wyłącznie na podstawie jednego rękopisu ${ }^{51}$.

Zaznaczyć też należy, że poza różnicami w składzie poszczególne egzemplarze tekstu często reprezentują odmienny układ ksiąg, który niekiedy stanowić może pierwszą wskazówkę dotycząca związków pomiędzy zachowanymi kopiami. Wydanie nie oddaje tych różnic ${ }^{52}$.

Jak zatem powiedziano, w literaturze przyjęto dotychczas istnienie trzech wersji odautorskich i dwóch współczesnych autorowi redakcji tekstu, pojawiają się też przypuszczenia o funkcjonowaniu kilku jego pośrednich form. Sięgając do egzemplarzy rękopiśmiennych, nie sposób jednak na tych kilku wersjach poprzestać, gdyż - prawdopodobnie ze względu na wyjątkową użyteczność - tekst Aurory szczególnie był podatny na wplatanie kolejnych uzupełnien' ${ }^{53}$. Dlatego też w części rękopisów odnaleźć można funkcjonujące zazwyczaj lokalnie, dodatki, nieuwzględnione przez wydawcę. Tę lukę sukcesywnie wypełnia G. Dinkova-Bruun, przygotowująca obecnie nowe, pełniejsze wydanie tekstu.

Wśród nieuwzględnionych w wydaniu tekstów zwrócić należy przede wszystkim uwagę na dwa zaniedbane fragmenty, których autorem z pewnością był Idzi. Po pierwsze, nie wydano dotychczas obecnego w 67 rę-

49 G. Dinkova-Bruun, The Story of Ezra: a Versification Added to Peter Riga's 'Aurora',, [w:] Anglo-Latin and its Heritage: Essays in Honour of A.G. Rigg on his 64th Birthday, ed. S. Echard i G. R. Wieland (Publications of the Journal of Medieval Latin, 4), Turnhout 2001, s. 164. Wcześniej G. Antonelli, dz. cyt., s. 778, zauważa istnienie rękopisów, które zawierają Dzieje Apostolskie, brak w nich natomiast Księgi Hioba i Pieśni nad Pieśniami.

${ }_{50}$ Zob. F. Stegmüller, Repertorium..., t. 4, nr 6824. Krytyczne wydanie wstępu: G. Dinkova-Bruun, Aegidius of Paris and the Seven Seals..., s. 119-145.

51 Aurora..., t. 1, s. LIII. Głębszej analizie należało by poddać m.in. fragmenty wydane w t. 1, s. 268-269, s. 310-311 i 313-315.

52 G. Dinkova-Bruun, Aegidius of Paris and the Seven Seals..., s. 120.

${ }^{53}$ Aurora..., t. 1, s. XXIV-XXVII. 
kopisach Mysterium de agno paschali (714 wersów), które w zamierzeniu autora miało zostać umieszczone po 216 wersie Księgi Wyjścia ${ }^{54}$. Po drugie, De penis infernalibus (116 wersów), znane również pod tytułem De penis inferni, doczekało się edycji wyłącznie na podstawie pojedynczego rękopisu w ramach serii Patrologia Latina ${ }^{55}$ oraz fragmentarycznego wydania przez P. E. Beichnera pod tytułem Aegidius on Himself ${ }^{56}$. Obecnie tekst znany jest już z trzynastu egzemplarzy ${ }^{57}$. G. Dinkova-Bruun zaznacza konieczność dokonania ponownej edycji ${ }^{58}$.

Szczególne miejsce zajmują wśród uzupełnień znane z 53 rękopisów Lamentationes Ieremiae ${ }^{59}$, zwane też Treni Ieremiae lub Lamentationes Lamentationum (440 wersów) - tekst spisany w rymowanych heksametrach, poprzedzony krótkim prologiem prozą. Wydawca pominął go, uznając, że nie mógł zostać spisany ani przez Piotra, ani przez Idziego $^{60}$. G. Dinkova-Bruun, opierając się na przesłance, że jest to jedyny tak licznie reprezentowany dodatek, sugeruje jednak, że Lamentationes mogły stanowić ostatnie uzupełnienie dołączone przez autora ${ }^{61}$. A zatem kodeksy, w których się znajdują, mogą reprezentować piątą redakcję odautorska.

Poza tym dotychczas zostały rozpoznane i częściowo wydane drukiem następujące uzupełnienia:

1. Tekst anonimowego autora, w rękopisie oznaczanego skrótem $A l$. lub Albtus, stanowiący uzupełnienie Ksiag Królewskich (932 wersy), który koncentruje się wyłącznie na wiadomościach natury historiograficznej z całkowitym pominięciem interpretacji alegorycznej, i świadczy o szczególnym zainteresowaniu, jakim darzono historię królów żydowskich. G. Dinkova-Bruun domyśla się, że autorem tekstu mógł być Albericus de Altovillari, magister scolasticus w szkole katedralnej w Reims w latach 1255-1266, bądź niedający się bliżej zidentyfikować Albertus

${ }^{54}$ G. Dinkova-Bruun, Aegidius of Paris and the Seven Seals.., s. 119, przyp. 5. Zob. Aurora..., t. 1, s. 99-100.9

55 PL 212, kol. 43c-46c.

${ }^{56}$ Aurora..., t. 1, s. 16-17, nr XI.

57 G. Dinkova-Bruun, Aegidius of Paris and the Seven Seals..., s. 119, przyp. 6.

58 G. Dinkova-Bruun, Additions to Peter Riga's Aurora in Paris, Bibliotheque nationale de France lat. 13050, „Medieval Studies”, 69:2007, s. 2, przyp. 6.

59 G. Dinkova-Bruun, „Proverbia Salomonis”: an Anonymous Accretion to Peter Riga's Aurora, [w:] Classica et Beneventana: Essays Presented to Virginia Brown on the Occasion of her 65th Birthday, ed. F. T. Coulson and A. A. Grotans (Textes et Etudes du Moyen Age, 36), Turnhout 2008, s. 10.

60 Aurora..., t. 1, s. XXV.

61 G. Dinkova-Bruun, Liber Ecclesiastes: An Anonymous Poem Incorporated in Peter Riga's Aurora (Ott. Lat. 399), „Miscellanea Bibliothecae Apostolicae Vaticanae”, VIII (Studi e Testi 402), Citta del Vaticano 2001, s. 161, przyp. 13. 
Remensis, autor dodanej do Aurory tzw. przedmowy nauczyciela ${ }^{62}$. Niezależnie od tożsamości autora rękopis związany był prawdopodobnie ze środowiskiem jednej z odznaczających się szkół katedralnych ${ }^{63}$.

2. Anonimowa Cantica Canticorum Beate Marie wydana drukiem na podstawie jednego przekazu ${ }^{64}$, obecnie znana z 11 rękopisów ${ }^{65}$.

3. Proverbia Salomonis - krótki (złożony z 300 heksametrów) wybór praktycznych porad etycznych, opierający się przede wszystkim na komentarzach Bedy, odnaleziony w ośmiu rękopisach ${ }^{66}$.

4. Liber Ecclesiastes (109 wersów), znany z czterech rękopisów ${ }^{67}$.

5. Dotychczas niewydany De excidio urbis Ierosolimorum, odnaleziony w trzech rękopisach ${ }^{68}$.

W pojedynczych kopiach zachowały się:

6. Liber Esdre Prophete, czyli złożony z 446 heksametrów (przede wszystkim leoninów) fragment odpowiadający dwóm kanonicznym Księgom Ezdrasza (w jednym miejscu odwołuje się do apokryficznej księgi trzeciej). Relacja biblijna została w nim zestawiona przede wszystkim ze Starożytnościami Józefa Flawiusza, można też zauważyć sporadyczne odwołania do Historia scholastica Piotra Comestora ${ }^{69}$.

7. Liber Esdre et Neemie (178 wersów), który podobnie odnosi się jedynie do warstwy historycznej dwóch kanonicznych ksiąg Ezdrasza, a jednak znacząco różni się charakterem od tekstu przywołanego powyżej. Odwołując się wyłącznie do wybranych i dobrze znanych wydarzeń, używa ich jako narzędzi mnemotechnicznych. Tekst spisano w dystychu elegijnym i, co ciekawe, zawarto po czwartej Księdze Królewskiej w rękopisie z uzupełnieniami autorstwa Alberica (zob. wyżej, punkt 1) ${ }^{70}$.

\footnotetext{
${ }^{62}$ Aurora..., t. 1, s. 4-7: Teacher's Preface.

${ }_{63}$ Bibliografia dotycząca postaci Alberica, zob. G. Dinkova-Bruun, Additions..., s. 3-4.

${ }^{64}$ P. E. Beichner, Cantica Canticorum Beate Marie, ,Marianum: Ephemerides Mariologicae", 21:1959, fasc. 2, s. 1-15.

65 G. Dinkova-Bruun, Peter Riga's 'Aurora' and its Gloss from Salzburg, Stiftsbibliothek Sankt Peter, MS a.VII.6, [w:] Insignis Sophiae Arcator: Essays in Honour of Michael W. Herren on his 65th Birthday, ed. by G. R. Wieland, C. Ruff and R. G. Arthur, Turnhout 2006, s. 239, przyp. 11.

${ }^{66}$ Wydanie: G. Dinkova-Bruun, Proverbia Salomonis..., s. 9-44 (zawiera oznaczenia miejsc zaczerpniętych z In Proverbia Salomonis Bedy).

67 G. Dinkova-Bruun, 'Liber Ecclesiastes': An Anonymous Poem..., s. 159-172; G. Dinkova-Bruun, Corrector ultimus..., s. 172, przyp. 2; G. Dinkova-Bruun, Peter Riga's 'Aurora' and its Gloss..., s. 239, przyp. 11. Zob. też F. Stegmüller, nr 6825.

68 G. Dinkova-Bruun, Peter Riga's 'Aurora' and its Gloss..., s. 239, przyp. 11.

69 Wydanie oraz analiza sposobu potraktowania źródłowego tekstu Antiquitates Józefa Flawiusza: G. Dinkova-Bruun, The Story of Ezra..., s. 163-88.

70 G. Dinkova-Bruun, Liber Esdre et Neemie: A Previously Unknown Accretion to Peter Riga's 'Aurora' from Manuscript Paris, BnF, Lat. 13050, „Mittellateinisches Jahrbuch", 48:2013, nr 2, s. 217-228.
} 
8. Pochodzący z tego samego rękopisu wiersz traktujący o księgach historycznych i profetycznych (272 wersy), spisany w dystychu elegijnym, w rękopisie zatytułowany: De Paralipomenon et de libris historiae et de prophetis (zob. wyżej, punkty 1 i 7) ${ }^{71}$.

9. Czterdzieści wersów traktujących o prorokach mniejszych, spisanych w dystychu elegijnym ${ }^{72}$.

10. Poza tym liczne anonimowe prologi proza ${ }^{73}$.

Wspomnieć też należy o jeszcze jednym przejawie aktywnej lektury, czyli o obszernych glosach. Wśród nich znany jest najlepiej Lucifer Aurorae $^{74}$, odnoszący się do wybranych miejsc, rozmieszczonych w całym tekście trzeciej redakcji. Fragment prologu do tego tekstu został omyłkowo wydany przez P. E. Beichnera jako A Thirteenth-century Foreword ${ }^{75}$. Przypisuje się go niekiedy Idziemu z Paryża, choć w rzeczywistości brak $\mathrm{ku}$ temu wystarczających przesłanek. Innym przykładem tego rodzaju twórczości jest glosa znana wyłącznie z jednego rękopisu przechowywanego w Salzburgu, opierająca się na drugim wydaniu Aurory i mająca charakter bardziej wybiórczy, gdyż część ksiąg całkiem pomija. Jej erudycyjność, w tym nieoczekiwane odwołania do mitologii, literatury klasycznej i filozofii, sugeruje związek ze środowiskiem uniwersyteckim. Zawarte w niej objaśnienia mają różnorodny charakter: uzupełnienia natury historycznej odwołują się przede wszystkim do tekstu samej Biblii lub do Historia scholastica Piotra Comestora. Glosatora interesują też kwestie związane ze stylem: komentuje figury retoryczne i metrum. Od niedawna dostępna jest edycja początkowego fragmentu tekstu, obejmującego objaśnienia do Księgi Rodzaju ${ }^{76}$.

Tak przedstawia się w zarysie skomplikowana kwestia ,zewnętrznego" kształtu Aurory, jej zawartości i rozpoznania autorstwa poszczególnych elementów. O wiele mniej powiedziano dotychczas o wewnętrznych cechach utworu.

Jeśli chodzi o znajdujący się w niej materiał egzegetyczny, Aurora $\mathrm{w}$ istocie nie jest $\mathrm{w}$ żadnej mierze nowatorska, choć za jej niewattpliwą

${ }^{71}$ G. Dinkova-Bruun, The story of Ezra..., s. 165; G. Dinkova-Bruun, Liber Esdre et Neemie..., s. 218; G. Dinkova-Bruun, Additions..., s. 5-6.

${ }^{72}$ G. Dinkova-Bruun, The story of Ezra..., s. 165.

73 Tamże.

${ }^{74}$ F. Stegmüller, Repertorium..., t. 4, nr 6826 wymienia pięć rękopisów, G. Dinkova-Bruun dodaje do tej listy dwa, zob. G. Dinkova-Bruun, Peter Riga's 'Aurora' and its Gloss..., s. 240, przyp. 14.

${ }^{75}$ Zob. Aurora..., t. 1, s. 3-4; G. Dinkova-Bruun, Peter Riga's 'Aurora' and its Gloss from Salzburg..., s. 240, przyp. 15.

${ }_{76}$ Glose super Auroram, Salzburg, Stiftsbibliothek Sankt Peter, MS a.VII.6, k. 49r104r, wyd.: G. Dinkova-Bruun, Peter Riga's 'Aurora' and its Gloss..., s. 231-260. 
zaletę uchodzi przedstawianie znanych idei w sposób dostosowany do potrzeb czytelników ${ }^{77}$. W podstawowym dla historii średniowiecznej egzegezy biblijnej opracowaniu autorstwa Beryl Smalley ${ }^{78}$ brak jakiejkolwiek wzmianki na temat Piotra Rigi, a Henri de Lubac w swoim sztandarowym dziele odnosi się do Aurory jedynie sporadycznie ${ }^{79}$. W warstwie egzegetycznej tekst opiera się przede wszystkim na Hieronimie, Grzegorzu Wielkim, Pateriuszu, Bedzie, Izydorze, Rabanie Maurze, Brunonie z Asti, Radulfie z La Tourte, Zachariaszu z Besançon, Piotrze Comestorze i Piotrze z Poitiers ${ }^{80}$. Śledzenie sposobu potraktowania źródeł ułatwiają zawarte w wydaniu noty, podające odniesienia do literatury, z której korzystał Riga. Poza tym Hans Oppemann poświęcił osobne studium relacjom pomiędzy tekstami Rigi i Comestora ${ }^{81}$. Odwołania są w tym przypadku na tyle znaczące, że niekiedy to właśnie temu drugiemu Piotrowi przypisywano autorstwo Aurory ${ }^{82}$.

To, co jest w Aurorze oryginalne, to sposób poetyckiego potraktowania tematu. Reprezentowany przez nią gatunek dzięki połączeniu tematyki biblijnej z atrakcyjną formą literacką cieszył się w średniowieczu ogromną popularnościa. Przyczyniły się do tego zarówno walory etyczne, związane z przekazywaniem moralnej nauki zawartej w Piśmie św., użytkowe - tego rodzaju utwory ułatwiały bowiem zapamiętanie treści Bibliii $^{83}$ i orientację w jej układzie, oraz estetyczne - Aurora stanowiła w swej epoce podręcznikowy wzorzec poetyckiego stylu i jest dziś jednym $\mathrm{z}$ istotniejszych dowodów rozkwitu poezji w XII wieku ${ }^{84}$. Mimo to temat

77 „Riga's versification of the Samson story clearly summarizes the traditional exegetical ideas developed by the poet's predecessors, but at the same time also succeeds in making Sacred Scripture relevant to the poet's contemporary readers by both issuing a warning against wickedness and providing hope for salvation", G. Dinkova-Bruun, Biblical Thematics: The Story of Samson in Medieval Literary Discours, [w:] The Oxford Handbook of Medieval Latin Literature, ed. R. Hexter, D. Townsend, Oxford 2012, s. 367-368.

${ }_{78}$ Zob. B. Smalley, The Study of the Bible in the Middle Ages, 3. wyd., Oxford 1984.

${ }^{79}$ H. de Lubac, Exégèse médiévale: les quatre sens de l'écriture (2 cz. w 4 tomach), Paryż, 1959-64, przekł. ang.: Medieval exegesis. The four senses of scripture, t. 1-3, Grand Rapids, Mich. 1998-2009.

${ }^{80}$ Aurora..., t. 1, s. XLVII.

81 H. Oppermann, Petrus Riga und Petrus Comestor, „Zeitschrift für romanische Philologie", 46:1926, s. 55-73.

82 Aurora..., t. 1, s. XXXIV-V, gdzie mowa przede wszystkim o Hugonie z Trymbergu i jego Registrum multorum auctorum.

${ }_{83}$ G. Dinkova-Bruun, The Verse Bible as Aide-Mémoire, [w:] The Making of Memory in the Middle Ages, ed. L. Doležalová, Leiden, Boston 2010, s. 115-131.

84 J.-Y. Tilliette, Verse style, [w:] The Oxford Handbook of Medieval Latin Literature..., s. 251. 
późnośredniowiecznych wierszowanych Biblii był dotąd zaniedbywany przez badaczy ${ }^{85}$, a styl samej Aurory do niedawna stanowił dla uczonych przykład złego smaku ${ }^{86}$. G. Dinkova-Bruun przedstawia panoramę tego zagadnienia, na jej tle ukazując także szczególną pozycję Aurory, wynikająca jej zdaniem z szerokiego ujęcia tematu poprzez odnoszenie się jednocześnie do historycznej, jak alegorycznej warstwy Biblii ${ }^{87}$. Szczególna popularność była też zasługa jasnego stylu, wyróżniającego Rigę na tle epoki ${ }^{88}$, pozwalającego jednocześnie na doskonałe oddawanie emocji i ukazywanie postaci o indywidualnej i bogatej osobowości ${ }^{89}$. Powyższe obserwacje zegzemplifikowane zostały w kilku studiach zestawiających wybrane watki biblijne zawarte w Aurorze z podobnymi tekstami, spisanymi w mniej więcej tym samym czasie. Porównano mianowicie sposób opracowania historii Samsona ${ }^{90}$, opisu stworzenia świata ${ }^{91}$ i opowieści o Jakubie i Józefie ${ }^{92}$. Ostatnie z opracowań ukazuje też twórczy sposób radzenia sobie $\mathrm{z}$ niespójnościami w tekście samej Biblii. O manieryzmie

${ }^{85}$ Zarys problematyki przedstawia G. Dinkova-Bruun, Biblical Versifications From Late Antiquity to the Middle of the Thirteenth Century: History or Allegory? [w:] Poetry and Exegesis in Premodern Latin Christianity. The Encounter between Classical and Christian Strategies of Interpretation, ed. W. Otten, K. Pollmann, Leiden, Boston 2007, s. 315-342.

$86 \mathrm{~Np}$. „ces taches, ce mauvais goût, qui déshonorent trop souvent le poëme de Pierre de Riga” (Histoire litteraire de la France, t. XVII, s. 34); „Misplaced ingenuity could go no farther [...]" (F. J. E. Raby, A History of Christian-Latin Poetry..., s. 304); „The introduction of rime into classical metres was, on the whole, disastrous. It began harmlessly with Gottschalk of Orbais, and culminated, in a fearful manner, with Peter Riga and Godfrey of Viterbo" (tenże, A History of Secular Latin Poetry in the Middle Ages..., s. 348). Podobnie wypowiada się B. Hauréau o Floridus aspectus (zob. B. Hauréau, Un poème inédit de Pierre Riga, „Bibliothèque de l'école des chartes”, 44:1883, nr 1, s. 11). Zob. też. M. Lapidge, Versifying the Bible in the Middle Ages, [w:] The Text in the Community: Essays on Medieval Works, Manuscripts, Authors, and Readers, ed. J. Mann and M. Nolan, Notre Dame, IN 2006, s. 11-40.

87 G. Dinkova-Bruun, Rewriting Scripture: Latin Biblical Versification in the Later Middle Ages, „Viator”, 39:2008, nr 1, s. 273 i 283.

${ }^{88}$ G. Dinkova-Bruun, Additions..., s. 1: „The clear style of the poem, the use of short sentences, often contained within the length of a single elegiac couplet, as well as the accessible way in which the poet presents the biblical story together with its complex allegorical interpretation made the work extremely suitable for use at the schools on both lower and higher level of education"; taż, Biblical Thematics: The Story of Samson, s. 367 i 368: ,Riga exhibits much higher poetic aspirations than his colleagues in both his rhetorical language and his carefully planned composition [...] Its text represents a skillful amalgamation of scholarly content, poetic mastery, and moral signification."

${ }^{89}$ G. Dinkova-Bruun, Rewriting Scripture..., s. 263-284.

${ }^{90}$ G. Dinkova-Bruun, Biblical Thematics: The Story of Samson..., s. 356-375.

${ }_{91}$ G. Dinkova-Bruun, Why Versify the Bible in the Later Middle Ages and for Whom? The Story of Creation in Verse, [w:] Dichten als Stoff-Vermittlung. Formen, Ziele, Wirkungen. Beiträge zur Praxis der Versifikation lateinischer Texte im Mittelalter, hg. P. Stotz unter Mitarbeit von P. Roelli, Zürich 2008, s. 41-55.

92 G. Dinkova-Bruun, Rewriting Scripture..., passim. 
formalnym Aurory w odniesieniu do Recapitulationes wspomina Janet $\operatorname{Martin}^{93}$.

Do tej pory kontrowersje budzi skomplikowana kwestia relacji pomiędzy Aurora a zbiorem Floridus aspectus. W polemikach badanie tradycji tekstu splata się z analizowaniem właściwości stylu obu dzieł. Początkowo panowało przekonanie, że Floridus aspectus był jedynie ekscerptem sporządzonym na podstawie Aurory ${ }^{94}$. Tej opinii, opartej zapewne wyłącznie na intuicji, przeciwstawił się P. E. Beichner, powołując się na zewnętrzne przesłanki, takie jak daty życia domniemanego adresata zbioru, czyli wspomnianego już wyżej arcybiskupa Samsona, a także na chronologię życia samego Piotra. Za oczywiste uznał bowiem, że jeśli przyjąć założenie o wcześniejszym powstaniu Aurory - oba dzieła musiałyby powstać przed 1161 r., kiedy Samson zmarł. A zatem Riga musiałby spisać je w czasach swojej młodości, by następnie na resztę życia porzucić pisarstwo ${ }^{95}$. Z powyższą opinią polemizuje G. Antonelli, kwestionujący wiarygodność tych chronologicznych przesłanek. Jak bowiem uzasadnia swoje stanowisko, po pierwsze, nie ma pewnych dowodów na to, że adresatem zbioru był faktycznie Samson - to przekonanie opiera się wyłącznie na interpretacji dokonanej przez B. Haureau, po drugie autor mógł zwracać się do patrona także po jego śmierci ${ }^{96}$. Odrzucając możliwość wyciagnięcia na tej podstawie pewnych wniosków, zestawia ze sobą kilka fragmentów występujących zarówno we Floridus aspectus, jak i Aurorze, starając się zaobserwować kierunek zmian wprowadzanych do tekstu. Krótkie studium G. Antonelliego doprowadziło go do stwierdzenia, że to Floridus aspectus zawiera tekst bardziej dopracowany pod względem stylistycznym, a ponadto - co mogłoby stanowić poważniejszy dowód słuszności tej tezy - zawiera poprawki wprowadzone przez Idziego. Na tej podstawie stara się też określić wkład, jaki Floridus aspectus wnieść powinien do krytycznego opracowania tekstu Aurory. Jak jednak sam zaznacza, jego wnioski nie opierają się na dokładnej analizie tekstów, co w przypadku tak skomplikowanej tradycji zdaje się istotnym

93 J. Martin, Classicism and Style in Latin Literature, [w:] Renaissance and Renewal in the Twelfth Century, ed. R. L. Benson and G. Constable with C. D. Lanham, Cambridge, Mass. 1982, s. 555-556. Zob. także: E. R. Curtius, Literatura europejska i łacińskie średniowiecze, Kraków 2005, s. 289, gdzie błędnie mowa o opisie dziejów świata autorstwa Rigi.

${ }_{94}$ M. Manitius, Geschichte..., t. 3, s. 821.

95 P. E. Beichner, The Floridus Aspectus of Peter Riga and some relationships to the Aurora, „Classica et Mediaevalia: Revue danoise de philologie et d'histoire”, 30:1969, nr 1-2, s. 451-481; Aurora..., t. 1, s. XV-XVI.

96 G. Antonelli, dz. cyt., s. 779-780; C. Wollin, Der 'Floridus Aspectus '... (I), s. 356, przyp. 6 . 
mankamentem, a odwoływanie się do dostępnych wydań, które wykorzystały niewielką część przekazów źródłowych, budzi poważne obawy. Zasadność twierdzeń G. Antonelliego podważa C. Wollin ${ }^{97}$. Decydującym wydaje się zresztą dowód kodykologiczny, który pozwala na określenie daty ante quem dla najstarszego spośród znanych obecnie kodeksów zawierających Floridus aspectus na rok $1181^{98}$.

Niezwykle istotnym aspektem w studiach nad Aurora jest bardzo szeroki zasięg jej oddziaływania. Objawia się on po pierwsze poprzez obecność w średniowiecznych programach szkolnych i w przywołujących jej autorytet traktatach dydaktycznych ${ }^{99}$. Wśród nich przede wszystkim wymienić należy Laborintus Eberharda z Bremy ${ }^{100}$ i Registrum multorum auctorum Hugona z Trymbergu ${ }^{101}$, Speculum maius Wincentego z Beauvais $^{102}$, skierowaną do paryskich studentów mowę Jakuba z Vitry ${ }^{103}$ i przeznaczony dla królewskiego potomka poemat dydaktyczny Carolinus Idziego z Paryża ${ }^{104}$. Aurora pojawia się też niejednokrotnie w szkolnym kontekście w różnorodnych tekstach, w których podstawową literaturę wzmiankuje się niejako przypadkiem, jak np. we wspomnianym wyżej liście nieznanego z imienia kleryka z Szampanii ${ }^{105}$ czy w dwóch lokalnych kronikach pochodzących z Frygii ${ }^{106}$. Odniesienia do niej znaleźć też można w tekstach dotyczących większości nauczanych dziedzin. Najłatwiej doszukać się ich w traktatach odnoszacych się do triwium, a zatem u leksykografów, gramatyków i retorów. Wśród tego rodzaju literatury Aurore przywołuje np. Catholicon Jana z Genui, Expositiones difficillorum verborum de Biblia Williama Brito, Distictiones monasticae, spisane prawdopodobnie przez angielskiego cystersa Radulpha Coggeshall, Ars

97 G. Antonelli, dz. cyt., s. 780, przyp. 38 i 39; C. Wollin, Der 'Floridus Aspectus' D... (I), s. 376 .

${ }_{98}$ Tamże, s. 357.

99 Zob. Aurora..., t. 1, s. XXX-XLII; E. R. Curtius, Literatura europejska i łacińskie średniowiecze, Kraków 2005, s. 57.

100 „Piotr Riga, skała, której wnętrze zrasza Chrystus, ukrył pod miodopłynnym stylem jedno i drugie Prawo" (Eberhard z Bremy, Laborintus, przekł. z jęz. łac., wstęp i przypisy D. Gacka, Warszawa 2011, s. 49).

101 Das Registrum multorum auctorum des Hugo von Trimberg... von J. Huemer, s. $145-190$.

102 Vincent of Beauvais, De eruditione filiorum nobilium, ed. A. Steiner, Cambridge, Mass. 1938, s. 23.

${ }^{103}$ Aurora..., t. 1, s. XXXIII, cytat za The Battle of the Seven Arts: A French Poem by Henry d'Andeli..., ed. and transl. by L. J. Paetow, Berkeley 1914, s. 16.

104 Histoire litteraire de la France, t. XVII, s. 29.

$105 \mathrm{H}$. Omont, Lettre relative aux oeuvres d'un auteur champenois de la fin du XII siècle..., passim.

106 Emonis et Menkonis Werumensium Chronica, ed. L. Weiland, MGH SS, XXIII, s. 524; Gesta abbatum Horti Sanctae Mariae, ed. L. Weiland, MGH SS, XXIII, s. 583. 
versificatoria Mateusza z Vendôme, Ecclesiale i Doctrinale Aleksandra z Villa Dei. Na wzmianki o niej można się jednak natknąć również w miejscach mniej oczywistych. Zaskakiwać może na przykład, że to właśnie na jej autorytet powołuje się Geoffrey Chaucer, gdy mówi o powstaniu muzyki. Literatura współczesna Ridze wiąże go zresztą z różnymi środowiskami edukacyjnymi: występuje zarówno jako przedstawiciel szkoły paryskiej, specjalizującej się w teologii (w Ecclesiale Aleksandra z Villa Dei), jak i jako reprezentant gramatyki (w La bataille de VII ars Henri' ego d'Andeli) ${ }^{107}$.

Najdobitniej o pozycji tego dzieła świadczy jednak wzorowana na nim późniejsza twórczość i przekłady na języki wernakularne. Od dawna wiadomo o wpływie, jaki Aurora wywierała na późniejszych autorów. Wzoruje się na niej np. biskup Ferrary Guido Capello (zm. ok. 1332), pisząc poemat Margarita Bibliae ${ }^{108}$. Zasygnalizowano również związki pomiędzy Aurora, a spisana w połowie XV w. Historia maior de fundatione et successione ecclesiae Wintoniensis Tomasza Rudborna ${ }^{109}$. Aurora stała sie też inspiracją dla tekstu, który w wielu rękopisach stanowił jej uzupełnienie, tzn. dla Hortus deliciarum Salomonis Hermana Werdinensis $(1225)^{110}$. Pomimo świadomości siły jej oddziaływania, zaskakująco owocnymi wydają się wyniki poszukiwań P. E. Beichnera, które objęły przede wszystkim teksty pochodzące $\mathrm{z}$ terenów Francji ${ }^{111}$.

Jak zostało udowodnione, na Aurorze opiera się niemal w całości obszerny tekst Biblii Macé de la Charité, pochodzacy z przełomu XIII i XIV w., stanowiący nie tyle jej przekład, co raczej adaptację na język starofrancuski. Luźny stosunek do pierwowzoru pozwolił na pomijanie bądź rozwijanie poszczególnych wątków, jeśli jednak chodzi o ogólną budowę tekstu, pominięte zostały jedynie końcowe Recapitulationes. Istotną różnica jest dodanie wywodzącej się z innego wzorca parafrazy Apokalipsy. P. E. Beichner zestawia z Aurora fragmenty tekstu udostępnione drukiem oraz sporządzone przez badaczy streszczenia pozostałej zawartości dzieła ${ }^{112}$.

Inaczej korzysta z Aurory zachowana w jednym egzemplarzu, pochodzacym z połowy trzynastego wieku, starofrancuska Biblia Jehana de Malkaraume. Ten autor zdaje się być szczególnie zainteresowany

107 Za Aurora..., t. 1, s. XL.

108 Histoire litteraire de la France, t. XVII, s. 30.

109 Zob. Aurora..., t. 1, s. XLVI. Wiedział o tym już P. Leyser, dz. cyt., s. 700.

110 Aurora..., t. 1, s. XXVI-XXVII.

111 Tamże, s. XLII.

112 P. E. Beichner, The Old French Verse Bible of Macé de la Charité, a Translation of the Aurora, „Speculum”, 22:1947, nr 2, s. 226-239; Aurora..., t. 1, s. XLII-XLIII. 
wartością retoryczną dzieła i podejmuje próbę przełożenia m.in. jednego z najbardziej znanych jego fragmentów, opisującego lament Jakuba nad synem. Również w tym przypadku P. E. Beichner przedstawił zestawienie analogicznych miejsc obu dzieł ${ }^{113}$.

Kolejnym ważnym spadkobiercą Aurory jest John Gower, który z tego samego tekstu korzysta w sposób całkiem odmienny. Otóż na potrzeby poematu Vox clamantis, będącego ilustracją kondycji poszczególnych stanów w dobie powstania Tylera Watta, sięga do Aurory bynajmniej nie ze względu na jej biblijną zawartość. Dla Gowera pierwszorzędne znaczenie mają walory retoryczne i poetyckie tekstu. Starając się je wykorzystać, często przejmuje poszczególne dwuwiersze, a nawet krótsze fragmenty, używając ich jako budulca w zupełnie nowym kontekście. Poza warstwą stylu Gower sięga często do pochodzących z Aurory alegorycznych interpretacji o charakterze moralizatorskim (P. E. Beichner zamieszcza w swoim artykule zestawienie analogicznych miejsc w obu tekstach, zastrzegając jednak niekompletność tego zestawienia) ${ }^{114}$.

Zaznaczyć tu też należy wpływ, jaki twórczość Piotra Rigi miała na średnioangielski poemat Cursor mundi, choć nie opiera się on na tekście Aurory, lecz na wersji pochodzącej z Floridus aspectus ${ }^{115}$.

Reasumując, powiedzieć można, że Aurora Piotra Rigi stanowiła i wciąż stanowi wyzwanie dla badaczy. Jej obraz w literaturze zaciemniały m.in. pojawiające się niejasności dotyczące identyfikacji autorów ${ }^{116}$, liczne wersje tekstu i jego podatność na przeróbki, nie mówiąc o drobniejszych nieścisłościach, jak chociażby funkcjonowanie różnych tytułów. Sytuację długo komplikował brak pełnego wydania, a i obecna edycja, stawiająca sobie przede wszystkim praktyczny cel udostępnienia tekstu szerszej publiczności, nie daje odpowiedzi na wszystkie pytania. Kolejną trudnościa jest brak kompletnego i opartego na szerszej podstawie źródłowej wydania Floridus aspectus, co z kolei uniemożliwia wyciąganie uzasadnionych wniosków na temat relacji pomiędzy tymi tekstami. Jednocześnie pomimo trudności - a może właśnie dzięki nim - Aurora stanowi też niezwykle bogate źródło wiedzy dotykające wielu aspektów

113 P. E. Beichner, La Bible versifiée de Jehan Malkaraume et l'Aurora, „Le moyen âge", 61:1955, nr 1-2, s. 63-78; Aurora..., t. 1, s. XLIII.

114 P. E. Beichner, Gower's Use of Aurora in Vox Clamantis, ,Speculum” 30:1955, nr 4, s. 582-595; Aurora..., t. 1, s. XLIV-XLV.

115 P. E. Beichner, The Cursor Mundi and Petrus Riga, „Speculum” 24:1949, nr 2, s. 239-250; Aurora..., t. 1, s. XLIII-XLIV.

116 Zob. G. Orlandi, Pluralitá di redazioni e testo critico, [w:] La critica del testo mediolatino. Atti del convegno (Firenze, 6-8 dicembre 1990), ed. C. Leonardi, Spoleto 1994, s. 98-99. 
szeroko pojętej historii umysłowości. Można w niej szukać wskazówek odnośnie średniowiecznego pojęcia autorstwa, transmisji tekstu, techniki poetyckiej. Szczególna popularność, jaką się cieszyła, zachęca też do pogłębienia wiedzy na temat wciąż niesprecyzowanego charakteru tej popularności ${ }^{117}$. Opierając się na badaniach proweniencyjnych samych kodeksów, jak i na informacjach odnoszących się do programów szkolnych na różnych poziomach edukacji, warto prześledzić, jaką dokładnie pozycję zajmował ów tekst. Dokładne studia pozwolić również mogą na uchwycenie specyfiki jego użycia w aspekcie chronologicznym i geograficznym. Na obecnym etapie badań nad zasięgiem oddziaływania Aurory w Polsce mogę potwierdzić, że był on niezwykle szeroki w wielu aspektach. Odnosi się to tyle do rozmieszczenia terytorialnego (mapa jej występowania jest stosunkowo gęsta), co chronologicznego (XIII-XV w.), oraz do jej rozmieszczenia na mapie intelektualnej (klasztory różnych zakonów, uniwersytet, środowisko mieszczańskie, być może szkoły niższego szczebla).

Szczegółowe zapoznanie się z jej rolą oraz określenie dróg recepcji będzie mogło natomiast stać się punktem wyjścia do poszukiwania odwołań do Aurory w późniejszych tekstach powstałych na ziemiach polskich, tym samym wpisując się w propozycje badawcze sformułowane przez Zenona Kałużę ${ }^{118}$ i Mieczysława Mejora ${ }^{119}$. Do podjęcia się tego zadania zachęca sugestia wydawcy, spodziewającego się w tego rodzaju badaniach kolejnego potwierdzenia ogromnego wpływu dzieła na późniejszą literaturę ${ }^{120}$.

117 Aurora..., t. 1, s. XXX: „The Aurora was used as a school text, but how early and how widespread the usage was cannot be determined with certainty".

118 Por. Z. Kałuża, O poetach i poezji w Kazaniach sapiencjalnych Skarbimierczyka. Studium źródtowe, „Przegląd Tomistyczny”, 10:2004, s. 33-86.

119 Mieczysław Mejor, Kanon lektur $i$ komentarze w polskim szkolnictwie XIV-XV wieku. Uwagi o cytatach, [w:] Septem Artes w ksztaltowaniu kultury umystowej w Polsce średniowiecznej (wybrane zagadnienia), red. T. Michałowska, Wrocław 2007, s. 137148.

120 „The final word on the popularity and influence of the Aurora in the Middle Ages has not yet been written. Versified Biblical material in other vernacular languages than French and English remains to be compared with the Aurora by other scholars. If allegorical interpretations have been given, they may perhaps be traceable to the Aurora. A study of the Middle Dutch Rymbybel of Jacob van Maerlant will probably show some influence of the Latin versified Bible of Peter Riga" (Aurora..., t. 1, s. XLVI-XLVII). 


\section{Streszczenie}

\section{Aurora - wierszowana Biblia autorstwa Piotra Rigi (ok. 1145-1209): stan badań i perspektywy}

Artykuł przedstawia stan badań nad Aurora, wierszowaną parafrazą Biblii spisaną pod koniec XII wieku przez Piotra Rigę (zm. 1209), kanonika katedry w Reims i kanonika mieszczącego się w tym mieście klasztoru augustianów, która jeszcze za życia autora przeredagowana została przez Idziego z Paryża (ca 1160-1224).

Opisywany tekst cieszył się w średniowieczu szczególną popularnością, na co dowodem jest blisko pięćset zachowanych do dziś kopii, liczne cytaty u autorów średniowiecznych i opierające się na nim kolejne przekłady. Jednakże pomimo szerokiego wpływu, jaki Aurora wywarła na średniowieczną umysłowość, editio princeps doczekała się dopiero w 1965 r., a choć dzieło stanowi doskonały materiał do badań nad wieloma aspektami odnoszącymi się do historii intelektualnej średniowiecza, dotychczas wiele związanych z nim zagadnień pozostaje nierozstrzygniętych.

Artykuł przytacza główne ustalenia dotyczące postaci autora oraz redaktora Aurory, kompozycji tekstu i specyfiki jego recepcji z zaznaczeniem trudności, wynikających $\mathrm{z}$ istnienia kilku wersji odautorskich oraz niemal jednocześnie sporządzonych redakcji. Ma na celu wprowadzenie do polskiej literatury przedmiotu zagadnienia do tej pory niemalże całkiem nieobecnego, a dającego nadzieję na nowe istotne ustalenia $\mathrm{w}$ zakresie transmisji tekstu i treści zarówno w odniesieniu do tego konkretnego przypadku, jak i w szerszej perspektywie panoramy intelektualnej średniowiecznej Polski.

Słowa kluczowe: Piotr Riga - Idzi z Paryża - literatura średniowieczna - egzegeza biblijna - wierszowane parafrazy biblijne.

\section{Summary}

\section{Aurora - a verse Bible by Petrus Riga (ca. 1145-1209): State and perspectives of research}

The article presents the state of research on Aurora, a verse paraphrase of the Bible composed prior to the end of the $12^{\text {th }}$ century by Peter Riga (died 1209), a canon of the Reims cathedral and a regular canon of the Augustinian monastery located in the same city. As early as during the lifetime of Riga, it was reworked by Aegidius of Paris (ca. 1160-1224). 
During the Middle Ages, Aurora was exceedingly popular. This popularity is attested by nearly 500 extant manuscript copies, numerous citations in works by other authors, and by translations into the vernacular. In spite of its importance to the Middle Ages, this remarkable text received its editio princeps only in 1965 , and even if this edition provides ample material for research on various themes relative to medieval intellectual culture, many issues connected with this text remain to be solved.

P. Pludra-Żuk recounts the major findings concerning Peter Riga and Aegidius of Paris, the composition of Aurora, and the specificity of its reception, emphasising the difficulties, which arise from the existence of several authorial versions of the text, and nearly contemporary redactions. Pludra-Żuk's article aims at introducing into Polish historiography issues related to Aurora, which hitherto have practically been absent, while the research field seems quite promising. In particular, one can hope for interesting results from inquiries into the textual transmission and the reception of the contents of Aurora, as well as the scrutiny of its place in the wider intellectual context of medieval Poland.

Key words: Peter Riga; Aegidius of Paris - medieval literature - Biblical exegesis - verse paraphrases of the Bible. 